3)圆城, 池内, 藤田：アルミニウムの㹡散接合に㧍讨る超音波振 動の影響, 軽金属, 36(1986), 498-506

4）大橋，橋本：昖散接合に関する研究（第1報）ーグロー放電によ る表面処理一, 本学会誌, 45 (1976), 76

5) 圓城, 池内： $\mathrm{Al}-\mathrm{Cu}-\mathrm{Mg}$ 系2017合金の抬散溶接，本会論文集， 2 (1984), 599-605

6) 圆城, 池内, 吉川：Al-Mg-Si系A 6063合金の拡散溶接におけ る接合界面の酸化皮膜, 日本金属学会，春期全国大会議演概要 集, (1986)，137

7) L. E. Davis:"Handbook of Auger Electron Spectroscopy",
Physical Electronics Industries, Second Edition, 1976, 5

8) 大阪大学理学部分析化学研究室：X線光䉓子スペクトルによる 電子束縛エネルギー・デー夕集, 1975,158

9) Physical Electronics Industries:Handbook of $X$-ray photoelectron spectroscopy.

10) J. R. Terrill, C. N. Cochran, J. J. Stokes, W. E. Haupin: Mechanism of Alumumum Brazing, W. J., 50 (1971), 833

11) 大橋, 田沼, 木村 : 拡散溶接部の密着部での酸化皮膜の挙動一 拡散溶接部での表面皮膜に関する研究（第3報）一，本会諭文集， $4-1$ (1986), 53-59

\title{
Ti-Zr 基ろうを用いたチタン接合部のミクロ組織*
}

\author{
恩㩐 忠男 ${ }^{* *}$, 鈴村 暁男**，高 明玩***
}

\section{Microstructure of Titanium Joint Made with Ti-Zr Base Brazing Fillers*}

by Tadao Onzawa**, Akio Suzumura*** and Myoung Wan Ko****

Microstructure of titanium joint made with developed $\mathrm{Ti}-\mathrm{Zr}$ base alloy brazing fillers has been investigated by observation and microanalysis with TEM, STEM/EDX, SEM/EDX, and X-ray diffraction test. Effect of heating time on the structure of the joint area was also examined in connection with diffusion of alloy elements in the fillers.

TEM microscopy revealed that the acicular structure at the joint area consists of more fine lamellar and cellular structures which form colonies similar to those commonly observed in eutectic and eutectoid. The configurations and diffraction patterns suggseted that these fine structures were eutectoid of $\alpha$-Ti and $\mathrm{Ti}_{2} \mathrm{Cu}$ containing $\mathrm{Zr}$, and that the joint area was made of proeutectoid $\alpha$-phase and the eutectoid.

Joint structure was remarkably affected by heating time. Particualrly the width of the region of these acicular structure at the joint area varies with heating time: firstly it increases to some extent, then decreases and finally disappears. According to the observation and analysis with SEM/EDX, the area of acicular structure was considered to correspond to such area as containing more amount of $\mathrm{Cu}$ and $\mathrm{Ni}$ than the solubility in $\mathrm{Ti}$ base metal. On this discussion, the width was also calculated by diffusion theory.

Key Words: Titanium, Titanium joint, Eutectoid, Brazing, Diffusion, Acicular structure

\section{1. 緒 言}

著者らはこれまでに, チタン及びチタン合金のろう付 用として一連の $\mathrm{Ti}-\mathrm{Zr}$ 基アモルファスろうの武作検討 を行うことにより，従来のチタン基ろうよりも約 $100^{\circ} \mathrm{C}$ 低い融点を持つ $\mathrm{Ti}-\mathrm{Zr}-\mathrm{Cu}-\mathrm{Ni}$ 万うを開発し，さらにそ の接合性について検討を行ってきた。その結果，そのろ うを用いるととにより工業用純チタン $(\mathrm{CPTi}) の \alpha-\beta$ 変態点及び $\mathrm{Ti}-6 \mathrm{Al}-4 \mathrm{~V}$ 合金の $\beta$ トランザス以下の温 度で接合が行え，かつ短時間の接合で母材の機械的性質 に匹敵し，また耐食性にす優れた継手が得られることを 示した1).

一方, 開発したろうはセラミックスに対するぬれ性す 良好であり，超高純度了ルミナセラミックスとチタンの 接合にあ応用できることも示した ${ }^{22}$ 。

本報では武作の $\mathrm{Ti}-\mathrm{Z} \mathbf{r}$ 基ろうによるチタンの接合部

\footnotetext{
*原稿受付 昭和63年7月25日 昭和62年度秋季全国大会で発表

**正員 東京工業大学工学部 Member, Faculty of Engineering. Tokyo Institute of Technology

***学生員 東京工業大学大学院 Student Member, Graduate School, Tokyo Institute of Technology
}

組織について透過電顕及び分析電顕等によるさらに詳し い観察及び分析を行い，また接合時間による接合部組織 の変化のメカニズムについても検討を行った。

\section{2. 供試材及び実験方法}

接合母材には主に CPTi ( 1 種)を用い，一部，等軸 $\alpha+\beta$ 銭造材の Ti-6 Al-4 V 合金を使用した. 万うとし ては，前報1で示した22種類の合金のうち，おもに 4 元 系の Type 1510 を厚さ $50 \mu \mathrm{m}$ のアモルファ ス箔に作製 して使用し，一部， 3 元系の Type 5000 についてあ検討 した. それらの化学組成及び融点を Table 1 亿示す.

継手形状子前報1) と同栏で, 丸棒 $(\phi 10 \times 15 \mathrm{~mm})$ の母 材 2 本を乫合せ, 真空中で $1 \mathrm{MPa}$ の接合圧力を加え高 周波誘導加熱により接合した。接合時間は，接合温度に

Table 1 Chemical compositions of filler metals used

\begin{tabular}{|c|c|c|c|c|c|c|}
\hline \multirow{2}{*}{$\begin{array}{c}\text { Filler } \\
\text { Metals }\end{array}$} & \multicolumn{2}{|c|}{ Chemical Compositions (wt.7) } & Liquidus & Solidus \\
\cline { 2 - 7 } & $\mathrm{Ti}$ & $\mathrm{Zr}$ & $\mathrm{Cu}$ & $\mathrm{Ni}$ & & $\begin{array}{c}\left.{ }^{\circ} \mathrm{C}\right) \\
\left({ }^{\circ} \mathrm{C}\right)\end{array}$ \\
\hline $\begin{array}{c}\text { Type } 1510 \\
\text { Type 5000 }\end{array}$ & 37.5 & 37.5 & 15.0 & 10.0 & 815 & 805 \\
\hline
\end{tabular}


到達後直ちに冷却する非常に短時間のものから24時間保 持のものまで種々変化させ, 組織を比較した。なお保持 時間を 2 時間以上とした場合は, 高周波炉中で 1 時間ま で加熱した後, 抵抗加熱型真空炉中で再加熱して行っ た. また, 接合面間隙の大きさと組織の関係について検 討する目的で, $\phi 10 \mathrm{~mm}$ の接合面の間に 0 最大 $120 \mu \mathrm{m}$ のテーパ状間隙を設けて接合した継手も作製した ${ }^{32}$.

接合後, 透過電顕 (加速電圧 $100 \mathrm{kV}$ ) による継手部の ミクロ観察, 電子線ならぴにX線回折, STEM/EDX, $\mathrm{SEM} / \mathrm{EDX}$ による継手部の分析を行った.

\section{3. 実験結果およひ考察}

\section{1 接合部のミクロ組織}

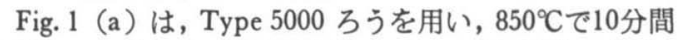
加熱して接合した CPTi 継手について, 接合面に平行に 研磨して露出させた接合部の組織と継手の断面組織を組 合わせて示したあのである. 接合温度が母材の $\alpha-\beta$ 変 態点以下のため, 断面組織に見られる接合母材は等軸な $\alpha$ 組織に保たれている。一方, 接合面に平行な面ではバ スケット状組織となっており, 粒界には粒界 $\alpha$ 相が, 粒 内には Widmanstätten 組織が観察されている. Fig. 1 (b) は, この面のX線回折結果であり, 六方晶の $\alpha \mathrm{Ti}$ 以外に正方晶の $\mathrm{Ti}_{2} \mathrm{Cu}$ が検出されている. 使用したろ うには $25 \mathrm{wt} \%$ の $\mathrm{Zr}$ が含まれており, 一方 $\mathrm{Zr}$ の固溶 により $\mathrm{Ti}$ の格子間距離が変化するという報告4すある. しかし, この回折パターンでは $\mathrm{Zr}$ の固溶による $\alpha \mathrm{Ti}$ お
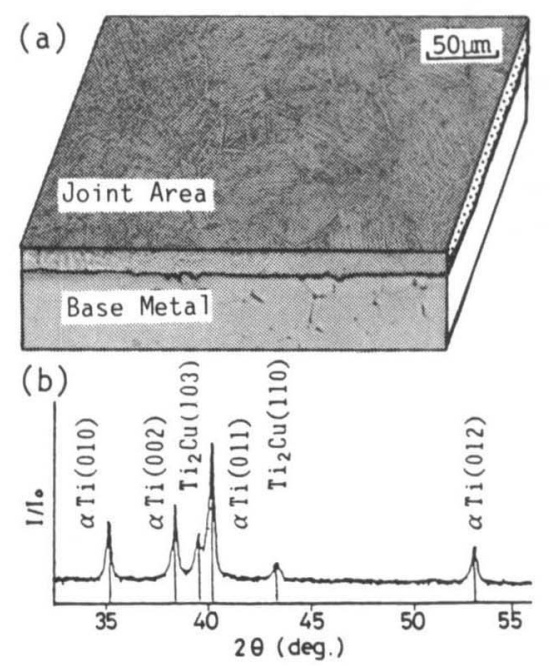

Fig. 1 Microstructure and X-ray diffraction pattern of CPTi joint made with Type 5000 filler.

Table 2 STEM/EDX point-analyses of joints made with Type 5000 filler

\begin{tabular}{|c|c|c|c|c|c|c|c|}
\hline Base Metals & $\begin{array}{l}\text { Brazing } \\
\text { Temp. }\left({ }^{\circ} \mathrm{C}\right)\end{array}$ & Zone & $\mathrm{Ti}$ & $2 r$ & $\mathrm{Cu}$ & Al & v \\
\hline $\mathrm{CP} \mathrm{Ti}$ & 850 & $\begin{array}{l}W Z \\
B Z\end{array}$ & $\begin{array}{l}95.0 \\
82.6\end{array}$ & $\begin{array}{l}5.0 \\
6.1\end{array}$ & 11.3 & - & - \\
\hline$T i-6 \mathrm{~A} 1-4 \mathrm{~V}$ & 900 & $\begin{array}{l}W Z \\
B Z\end{array}$ & $\begin{array}{l}76.0 \\
69.8\end{array}$ & * & $\begin{array}{r}3.8 \\
11.7\end{array}$ & $\begin{array}{l}7.2 \\
6.5\end{array}$ & $\begin{array}{l}13.0 \\
12.0\end{array}$ \\
\hline
\end{tabular}

よび $\mathrm{Ti}_{2} \mathrm{Cu}$ の格子間距離は余り影響を受けていないと いう結果になっている。乙れは，たとえば Table 2 の分 析結果にああるが, 接合加熱時に Zr の濃度が急速に減 少することを示している。

接合部では, $\mathrm{Zr}$ の他 $\mathrm{Cu}$ の濃度も急速に減少してい る.乙れらの原因としては, 液相ろうによる母材の溶 解, 接合圧力による液相の排出の他, Fig. 6 および Fig. 8 でも触れるが等温凝固が急速に進むとと, 等温凝固終 了時に液相線濃度から固相線濃度に急激に濃度が減少す ることなどあ考えられる。

Fig. 2 は, Type 5000 ろうによる継手部の TEM 観 察用薄膜の光顕写真及びその中に円で囲った継手中心部

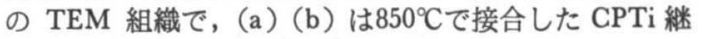
手, (c)(d) は $900^{\circ} \mathrm{C}$ で接合した Ti-6 Al-4 V 継手のもの である. 光顕写真では明瞭でないが, TEM 組織観察に よると CPTi 継手部は凮状組織となっており, Ti-6 Al$4 \mathrm{~V}$ 継手部は Widmanstătten 組織及び析出物と思われ る細かい組織から成っていることが分かる。これらの 組織の部分を STEM/EDX により点分析した結果を Table 2 に示す. いずれの場合も白く観察される部分 (WZ) では $\mathrm{Cu}$ が減少しているのに対し, 黒く観察され る部分 (BZ) では $\mathrm{Cu}$ が富化している.しかし, この黒 い部分であ Fig. 1(b) のX線回折結果で示された $\mathrm{Ti}_{2} \mathrm{Cu}$ の組成にはなっていない，乙れはこの組織が微細であ り, 分析に要した STEM/EDX の電子ビーム径（約 $100 \mathrm{~nm}$ ) より狭いため, 実際の量より Cu が少なく測定 された結果と考えられる.

次に，4元系の Type 1510 ろうを用い, $850^{\circ} \mathrm{C}$ 亿加熱 後ただちに自然冷却させて接合した CPTi 継手 部の, TEM 組織および電子線回折パターンを Fig. 3 に示す. 母材組織 (a) が等軸 $\alpha$ 相になっているのに対し, 母材 と接合部の境界付近（b) の組織は母材の $\alpha$ 相とは異 なった組織となっている。 これは短時間の加熱にもかか わらず, この部分の母材が溶融ろうにより溶解されたと とを示唆している, 一方, 接合層の中央部 (c) は, 層状, 棒状およびセル状の混合組織となっており, 共晶あるい
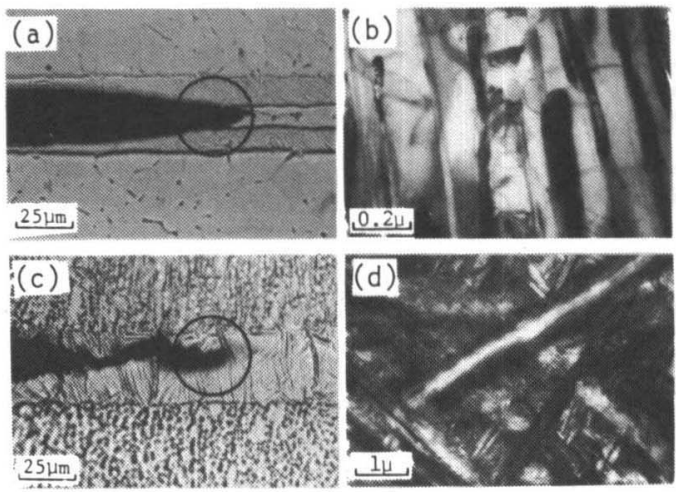

Fig. 2 Optical images of thin films for TEM observation and TFM images at the center of each joint made with Type 5000 filler.

(a)(b) CPTi joint made at $850 \mathrm{C}$ for $5 \mathrm{~min}$.

(c)(d) Ti-6AI-4V joint made at $900 \mathrm{C}$ for $5 \mathrm{~min}$. 

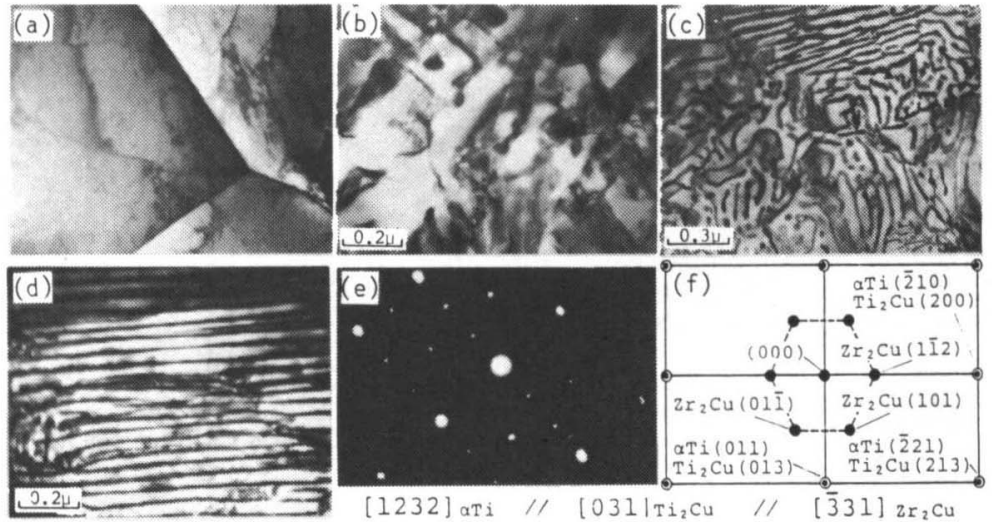

Fig. 3 TEM images and electron diffraction pattern of CPTi joint made without holding after heating up to 850C.

(a) Base metal (b) Joint interface (c)(d) Center of the joint

(e)(f) Diffraction pattern at the site shown in (d).
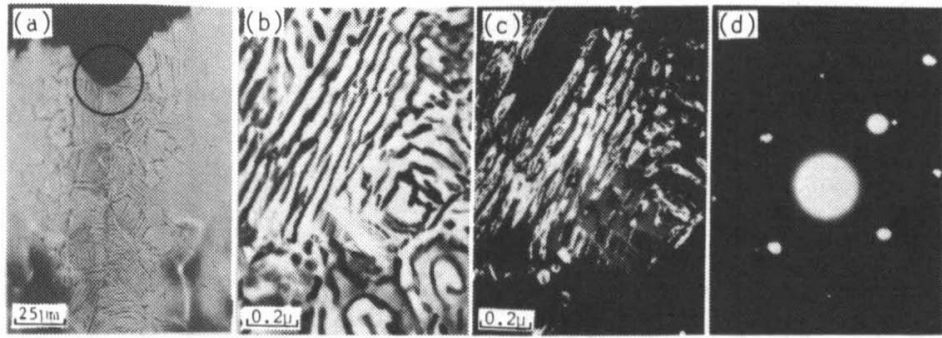

Fig. 4 Optical images of thin films and TEM images of CPTi joint made with Type 1510 filler at $860 \mathrm{C}$ for $5 \mathrm{~min}$.
(a) Observed area
(b) TEM bright-field image
(c) Dark-field
image
(d) Diffraction pattern.

は共析組織でよく見られるコロニー組織が観察される。 また，接合部中には一部，(d)のような微細な首状組織 あ見られた。この部分の電子線回折パターン及びその図 解を (e) および (f) に示す. ここで図解中の白丸とそ の中の黒丸は各々 $\alpha \mathrm{Ti}$ と $\mathrm{Ti}_{2} \mathrm{Cu}$ のパターンを表してお り, 両者はほほ重なっている。この回折結果によると, この屏状組織の黒い部分は $\mathrm{Ti}_{2} \mathrm{Cu}$ と $\mathrm{Zr}_{2} \mathrm{Cu}$ の混合組織 で,その間の白い組織は微量の $\mathrm{Zr}$ を含んだ $\alpha \mathrm{Ti}$ であ ると考えられる.

Fig. 4 に Type 1510 のろうを用い, $860^{\circ} \mathrm{C} て ゙ 5$ 分間保 持した継手部の光顥組織, およびその中に円で囲って示 した継手部の TEM 組織を示す. 明視野像 (b) は Fig. 3(c) と同様であり, 比較的短時間の加熱保持の場合, 継 手部の組織は基本的には変化せず共析組織となってい る. しかし, この部分の電子線回折パターン (d) の解析 の結果では, ASTM カード中に該当するすのは見いだ せなかった。これは， $\mathrm{Zr}$ の固溶により格子間距離が変 化していることを示唆している。

以上の結果は, Fig. 5 の Ti-Cu 系 2 元状態図(5)を用い ると次のように考察される。まず Type 5000 ろうを用 いた場合， $\mathrm{Ti}-\mathrm{Cu}$ 合金に $\mathrm{Zr}$ を添加することにより $\mathrm{Ti}-$ $\mathrm{Cu}$ の共晶点が移動し, Table 1 にあるように融点は約 $815^{\circ} \mathrm{C}$ まで低下する。 このろうを用い, $850^{\circ} \mathrm{C}$ 温度で加 熱保持すると, 融点降下元素に相当する $\mathrm{Zr}$ 及び $\mathrm{Cu}$ が

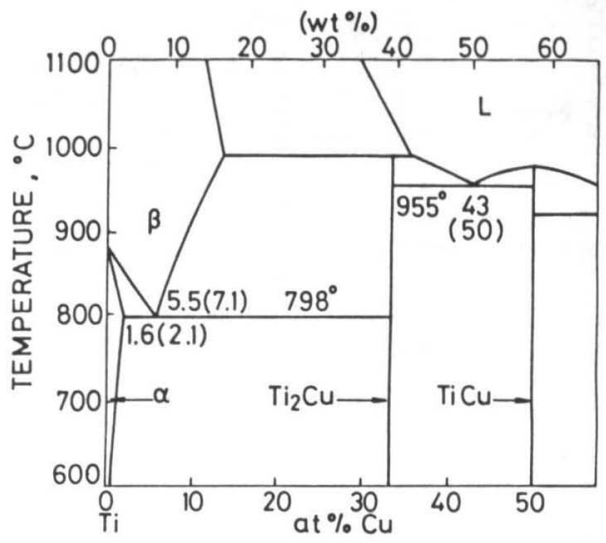

Fig. 5 Ti-Cu binary phase diagram.

母材中へ拡散していき, 接合部は $\mathrm{Ti}-\mathrm{Cu}$ の 2 元系に近 い組成になる。そこで, Fig. 5 の状態図を参照すると， 接合部は接合後の冷却途上約 $800^{\circ} \mathrm{C}$ 付近で共析反応を起 こし， $\mathrm{Zr}$ を固溶した $\alpha \mathrm{Ti}$ と金属間化合物の $\mathrm{Ti}_{2} \mathrm{Cu}$ の 2 相に分離すると考えられる. $\mathrm{Zr}$ は $\mathrm{Ti}$ に固溶するた め, 主に Cu の濃度に従って共析, 過共析あるいは亜共 析の組織が継手部に形成される. 


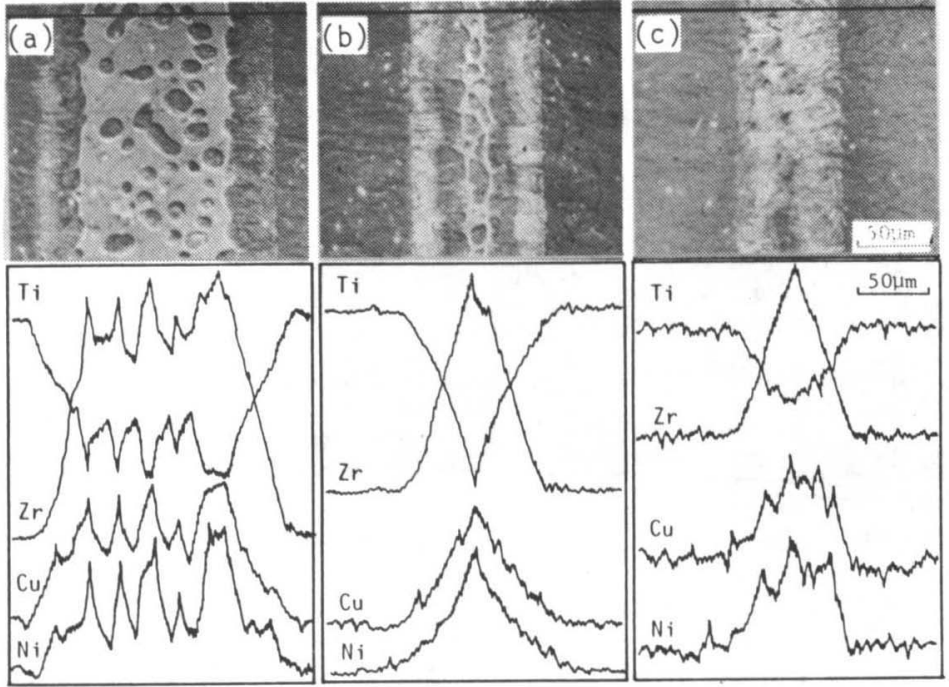

Fig. 6 SEM images and EDX analyses of CPTi joint made by setting tapered clearance and heating at $850 \mathrm{C}$ for $10 \mathrm{~min}$ with Type 1510 filler.
(a) Thick joint layer
(b) Middle area
(c) Thin joint layer.

一方, Type 1510 ろうの場合は Ti-Zr-Cu 3 元合金に さらに Ni が添加されているが, この場合も Type 5000 ろうを用いた場合と同様, 常温ではほほ共析組織になっ ている。しかし, Type 5000 ろうよりも Zr の含有量が 多いため $\alpha \mathrm{Ti}$ 及び $\mathrm{Ti}_{2} \mathrm{Cu}$ に固溶する $\mathrm{Zr}$ 量も多くな り, 接合部の組成によっては $\mathrm{Ti}_{2} \mathrm{Cu}$ よりあむしろ $\mathrm{Zr}_{2} \mathrm{Cu}$ に近い格子間距離をむつ金属間化合物屯生成される．し かし，いずれの場合も接合部は $\alpha \mathrm{Ti}$ 及び $\mathrm{Ti}_{2} \mathrm{Cu}$ 型の金 属間化合物で構成されており, これらに $\mathrm{Zr}$ が固溶した 状態と考えられる。

\section{2 接合時間による継手部組織の変化}

前節では比較的短時間で接合した継手部の微小組織に ついて検討した。ここでは接合時間を変えた場合の各元 素の拡散状態と接合部の組織変化の関係について調べ た。

まず，接合に使用されるろうの量と継手組織の関係を 調べる目的で, 接合面間隙をテーパ状に連続的に変化さ せ, Type 1510 のろうにより $850^{\circ} \mathrm{C}$ で 10 分間接合した CPTi 継手の組織及び元素分布を Fig. 6 亿示す.組織中の 黒線は線分析位置を示している。間隙の広い継手部 (a) の中心部はマトリックス中に球状の粒子が混在する疑固 組織となっている。線分析結果によると球状組織では $\mathrm{Ti}$ の濃度が高く, その分 $\mathrm{Zr}, \mathrm{Cu}, \mathrm{Ni}$ の濃度が低くなって いる.点分析によると球状部分では Ti 濃度が $65 \mathrm{wt} \%$ 以 上を示し，一方，マトリックスに当たる部分ではほほ元 のろうと同じ組成となっていた，てのマトリックス部分 をさらに高倍率で観察した結果, この部分にも微細な縞 状組織が観察された。すすなわちこの場合の接合部では， 球状部とその間のマトリックス部分との共晶が形成され た後,さらにマトリックスが共析変態したと考えられ る.なお, この疑固組織と母材との境界部には凝固組織 中の球状組織とほほ同じ組成の領域が有り, その外側に は針状の変態相が形成されている.

接合面の間隙が狭くなると，(b)のように継手中心部

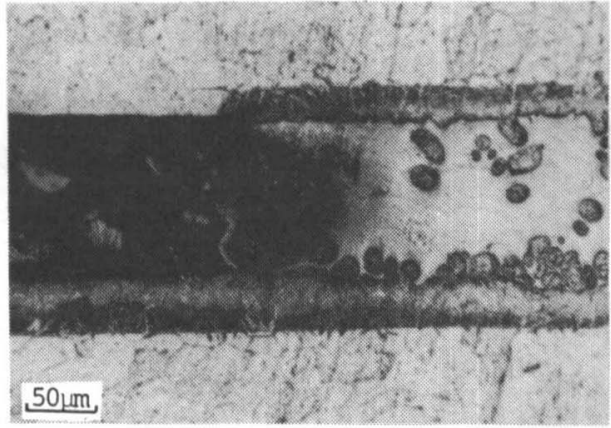

Fig. 7 Optical structure at the edge area of liquid filler observed in the joint with tapered clearance shown in Fig. 6.

の疑固組織の幅屯狭くなり, また共晶部分にあるような 凹凸は濃度分布に見られなくなっている。間隙がさらに 狭く約 $70 \mu \mathrm{m}$ の場合（c)では, 10分間の接合時間であ 冷却凝固によると思われる組織は観察されなくなり，こ の部分はいわゆる等温凝固により凝固したことを示して いる. なお， との部分の $\mathrm{Cu}, \mathrm{Ni}$ および $\mathrm{Ti}$ は鋸歯状の 分布をしているが, これは接合部の冷却途上の共析変態 によるあのと考えられる。

Fig. 7 は, Fig. 6 に示したテーパ型間隙を設けた武片 の最む広い間隙の部分の組織で, 黒く見える部分は接合 されていない部分である. 溶融ろうがぬれていない母材 表面とろうの存在する部分の母材表面は, ほほ一直線状 になっており， $\mathrm{Ni}$ 基耐熱合金の液相拡散接合の場合 等 に一般に観察されるような著しい母材の溶解 ${ }^{6-7)}$ は生じ ていないととが分かる。乙れは, 本研究の場合 CPTi の 変態点を考慮し, ろうの融点よりわずかに高い温度で接 合しているため, ろう中の $\mathrm{Cu}, \mathrm{Ni}$ 等の融点降下元素か わずかに減少しただりで，乃うの融点が接合温度よりも 


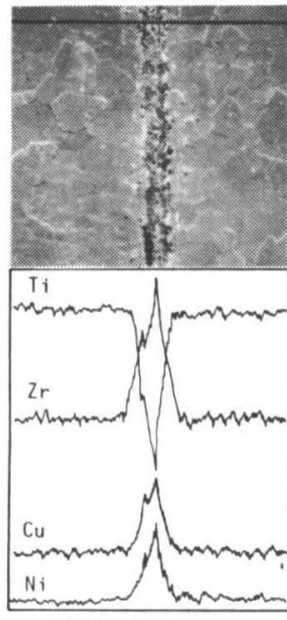

(a) 0 min

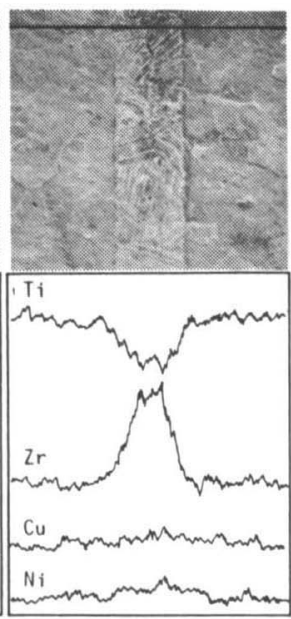

(b) $10 \mathrm{~min}$

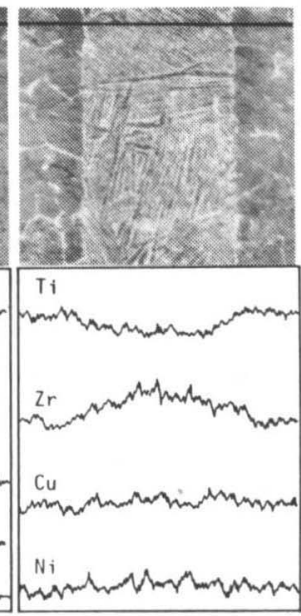

(c) 60 min

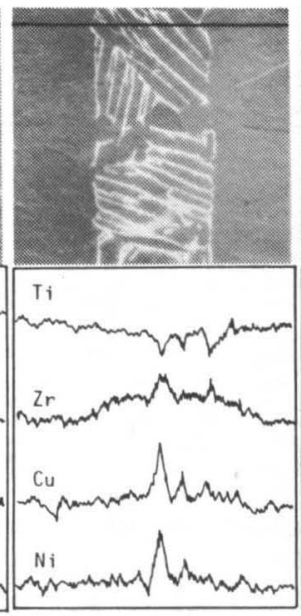

(d) 120 min

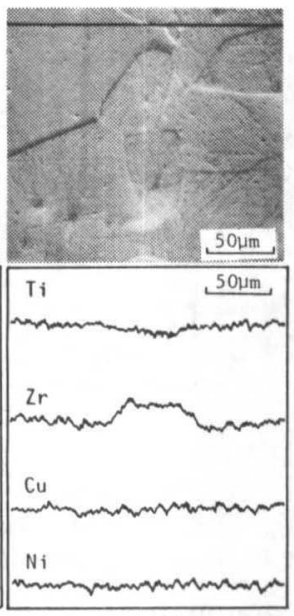

(e) $1440 \mathrm{~min}$

Fig. 8 Changes in the structure and diffusion profile at the joint with holding time at $850 \mathrm{C}$.

高くなる結果と考えられる.

Fig. 8 に Type 1510 を用い, 接合温度を $850^{\circ} \mathrm{C}$ 亿一定 にし接合時間を変えて接合した CPTi 継手部の組織及び 組成の変化を示す. 接合温度に到達後ただちに冷却させ た接合部 (a) の微細組織については既に Fig. 3 に示し たが, ここでは母材と異なる組織を示している領域の幅 に集目すると, 約 $20 \mu \mathrm{m}$ になっている，接合時間が10 分の場合の接合部 (b) では Fig. 6(a)のような組織は観 察されず, 既に等温凝固が終了していると考えられる. 各成分の均質化はかなり進行しており, 接合部には約 $50 \mu \mathrm{m}$ の共析変態相が形成されている. (c) の接合時間 60分の場合には，その幅がさらに広がって約 $115 \mu \mathrm{m}$ に なっている。 また接合部の $\mathrm{Cu}$ 及び $\mathrm{Ni}$ はほぼ均一に なっている。乙れに対し，接合時間がさらに長くなり， 120 分間加熱した場合の接合部 (d) では母材と異なる組 織の幅は逆に減少しており, 更に接合時間が長くなると (e) のように接合部の組織は母材とほほ同一になってい る.

このように接合部では接合時間の増加に伴い，まずか なり短時間で等温凝固が終了し, その後, 単に組成が均 一化して行くだけでなく, 組織にも著しい変遷が見ら れ. これは, $\mathrm{Ti}$ 中における固溶限を越えた $\mathrm{Cu}, \mathrm{Ni}$ 等 の存在する領域が接合部の冷却中に共析変態するためで あり, その領域の幅が元素の拡散により一旦ある範囲ま で増加した後, 減少して行くことに対応していると考え られる.

そこで次に, この変態領域の幅の変化について固相内 の拡散理論により計算してみる．接合部における溶質 元素の濃度分布変化を Fick の第二法則の式 $\partial C / \partial t=$ $D \partial^{2} C / \partial x^{2}$ の薄膜拡散源 $M$ 飞対する解 ${ }^{8)}$

$$
C=\frac{M}{2 \sqrt{\pi D t}} \exp \left(-\frac{x^{2}}{4 D t}\right)
$$

で表せるとすると, 模式的に Fig. 9 のようになる. Fig. 9 は, $t_{1} \sim t_{4}$ 秒後の濃度分布を示しており, 図中の $C_{\mathrm{a}}$ は溶質の固溶限である. こてで, $\mathrm{W}_{1} \sim \mathrm{W}_{3}$ は各々 $t_{1} \sim t_{3}$ 秒後の変態領域の幅を表しており, $t_{4}$ 秒後ではその幅は

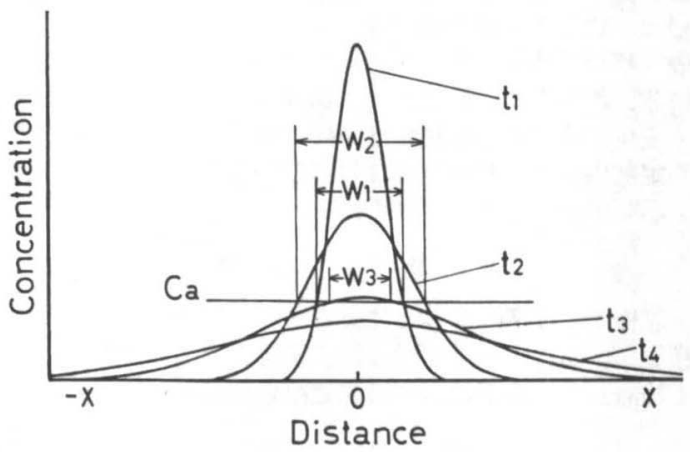

Fig. 9 Schematic illustration showing the relation between the width of eutectoid-transforming area and diffusion profiles.

ゼロとなっている. ことで固溶限 $C_{\mathrm{a}}$ 以上の濃度をむつ 部分で共析変態するとし, その幅を $\mathrm{W}(=2 x)$ とすると,

$$
x^{2}=-4 D t \cdot \ln \left(2 C_{\mathrm{a}} \sqrt{\pi D t} / M\right)
$$

\section{より $\mathrm{W}$ が求まる.}

接合温度が $850^{\circ} \mathrm{C}$ の場合の変態領域の幅の変化につい て，(2)式により計算した結果を Fig. 10 に示す. ここで, 拡散係数 $D$ は $\mathrm{Ti}$ に対する $\mathrm{Cu}$ の振動数因子 $D_{0}$ 及び 拡散の活性化エネルギーQの文献值泉から計算した。 た, $\mathrm{Ti}$ における $\mathrm{Cu}$ の固溶限 $\mathrm{Ca}$ は, Fig. 8(d) におけ る母材 $\mathrm{Ti}$ と接合部との境界部分の $\alpha \mathrm{Ti}$ での $\mathrm{Cu}$ 濃度 の測定值 $(0.54 \mathrm{wt} \%)$ を用いた。一方, 拡散源 $M$ につ いては時間的変化がないと考え, 測定の容易な Fig. 8 (a) 中の $\mathrm{Cu}$ の線分析結果より求めた. また, との線分 析結果を初期濃度 $C_{0}$ を一辺とする矩形に近似して, 初 期の接合屏の幅 $h_{0}$ を算出した。拡散源の初期濃度 $C_{0}$ を一定にし， $h_{0}$ を変化させた場合についての変態領域 の幅屯計算し, これらと実際の組織より測定した変態領 域の幅（図中の黒丸）を比較してある.

Fig. 8(a) より計算される $h_{0}$ が $20 \mu \mathrm{m}$ の場合につい 


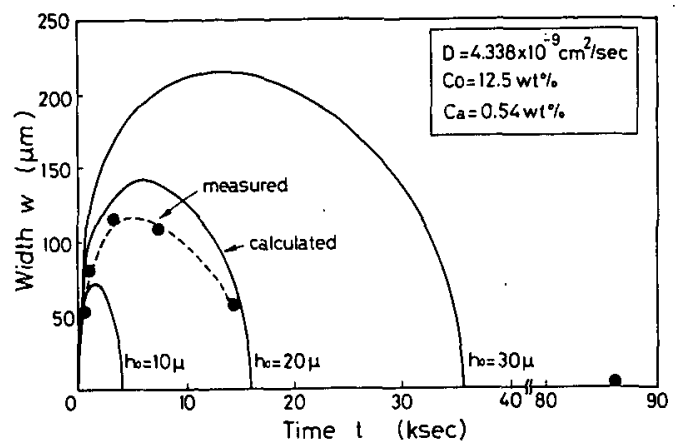

Fig. 10 Effect of holding time on the width of transforming region. Calculated lines are compared with measured widths.

て変態領域の幅を計算した結果によると，加熱時間 6 $\mathrm{ksec}$ までは接合部の針状層の幅は增大して行き，最大幅

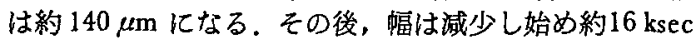
の加熱時間で変態㞒は消失する。乙の場合の実際の組織 より測定した変態領域の幅と比較すると, 両者の傾向は ほほ一致していると言える．一方， $h_{0}$ の増加と共に， 最大幅及び消失に要する時間す增加することも示されて いる.乙れらの計算結果は， $D, C_{0}, C_{\mathrm{a}}$ の值により大き く変化するが概略の傾向は同様になる.Fig. 8 に対する 椡定結果も計算結果とほぼ対応しており，計算の姩当性 を示していると考えられる。

\section{4. 結}

試作の $\mathrm{Ti}-\mathrm{Zr}$ 基万うによるチタン接合部のミクロ組

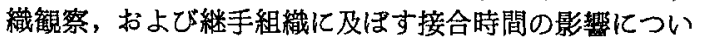
て検討した，以下に，本研究で得られた主な結果及び結

\section{論を要約する。}

(1) $\mathrm{Ti}-\mathrm{Zr}$ 基ろうによる $\mathrm{Ti}$ 接合継手部は接合後の冷

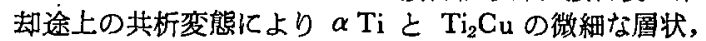
棒状およびセル状組織を示し，てれらに Z r が固溶した 状態になっている。

（2）溶融万うにより溶解される母材の量は比較的少な い. また, $\mathrm{Zr}, \mathrm{Cu}, \mathrm{Ni}$ 等の融点降下元素が母材中へ拡 散し，接合部は急速に等温凝固している.

（3）接合部に観察される母材組織と翼なる針状組織の 領域は， $\mathrm{T}_{\mathrm{i}}$ 中における固溶限以上の $\mathrm{Cu}, \mathrm{Ni}$ を含む領 域に対応し，ての部分で共析変態を起てす。

(4) 接合部の変態領域の幅は，接合時における元素の 拡散の進行により，一旦增加したのち娍少し始め, やが て消失する.この過程は拡散理論により計算した結果と 概略一致する。

\section{参考文 献}

1) 恩沢, 鈴村, 高 : Ti系アモルファスろうによるCP Ti及びTi. $6 \mathrm{Al}-4 \mathrm{~V}$ 万う付緇手の組織と機械的性質，本誌 $5-2(1987), 21$

2）恩沢, 鈴村, 高；Ti-Er基ろうを用いた超高純度アルミナとチタ． ンのろう付性, 本誌, 7-1 (1989) 124

3) 坂本, 藤原： Ni基耐熱ろう付プロセスの最適化，第8回界面接合 委員会資料, No. IJ $-12-87$ (1987)

4) A. D. McQuillan and M. K. McQuillan;Titanium, Butterwor. ths Scientific Publications(1956), 277

5) M. Hansen;Constitution of Binary Alloys, McGraw-Hill (1958), 643, 1050

6）鉿村，恩沢，田村：液相㹡散接合性に及ぼすインサート金属の アモルファスの効果, 本誌, 3-2 (1985), 85

7) Y. Nakao, K. Nishimoto et al.; Transient Liquid Insert Metal Diffusion Bonding of $\mathrm{Ni}-$ Base Superalloy, MM 007, IIW. Doc. $1 \mathrm{~A}-334-86-0 \mathrm{E}$ (1986)

8) 笛木, 北沢 (共訳)；固体内の昖散, コロナ社(1986), 8

9）日本金属学会編：金属データブック，丸善(1974)，27

\title{
Ti 基ろうによる Ti-21V-4Al $\beta$ 型チタン合金の 液 相 拡散 接 合*
}

\author{
恩澤 忠男**，鈴村 暁男 ${ }^{* *}$ ，高 明玩***
}

\begin{abstract}
Diffusion Brazing of Ti-21V-4Al $\beta$-Type Titanium Alloy Using Ti-Base Filler*
\end{abstract}

$$
\text { by Tadao Onzawa**, Akio Suzumura** and Myoung Wan Ko*** }
$$

Diffusion brazeability of $\beta$-type $\mathrm{Ti}$ alloy (Ti-21V-4Al) using newly developed Ti-20Zr-20Cu-20Ni amorphous filler has been investigated by electron microscopy, EDX microanalyses, and tensile tests of the joints. The brazeability was compared with solid state diffusion bondability of the same material, and the effect of aging heat treatments of the joint generally carried out for the alloy was also examined.

Results of metallurgical examination of the joints indicated that the liquid layer at the joint interface became to disappear during holding at the joining temperature, and that the joint structure and composition finally became similar to those of the base metal.

As for mechanical properties of the joint, even the joint made at $850 \mathrm{C}$ for $15 \mathrm{~min}$ under the joining

\footnotetext{
*原稿受付 昭和63年11月21日 昭和63年度秋李全国大会で発表

**正員 東京工業大学工学部 Member, Tokyo Institute of Technology, Faculty of Engineering

***学生員 東京工業大学大学院 Student Member, Tokyo Institute of Technology, Graduate School
} 